\title{
Essential Oil Composition of Endemic Pimpinella tunceliana Yıld. from Turkey for the First Time
}

\author{
Ömer Kilic $^{1}$ and Şinasi Yildirimli ${ }^{2}$ \\ 1. Technical Science Vocational College, University of Bingol, Bingol 12000, Turkey \\ 2. Department of Biology, Science Faculty, University of Hacettepe, Ankara 06000, Turkey
}

\begin{abstract}
The objective of this study was to examine the essential oil of Pimpinella tunceliana Y1ld. growing wild in the Eastern part of Turkey for the first time. Obtained results were discussed with the genus patterns and natural products. The essential oil of $P$. tunceliana was analyzed by head space-solid phase microextraction (HS-SPME)/gas chromatography-mass spectrometry (GC-MS) technique, and 50 compounds were identified, representing $96.3 \%$ of the oil. The main constituents of $P$. tunceliana were $\beta$-caryophyllene (13.9\%), $\beta$-bisabolene (10.4\%), anethole (9.3\%), sabinene (7.5\%), limonene (6.9\%) and germacrene D (6.8\%). In this study, essential oil contents of $P$. tunceliana that is a new and endemic species was studied for the first time, and important results were presented in respect to the composition of the oil of this new species of Pimpinella.
\end{abstract}

Key words: P. tunceliana, essential oil, HS-SPME/GC-MS.

\section{Introduction}

The Apiaceae (Umbelliferae) family has a cosmopolitan spreading, but most of Apiaceae taxa are confined to Northern temperate areas and high altitudes in the tropic regions [1]. Apiaceae, in Turkey called Dereotugiller or Maydanozgiller, has annual and perennial herbs, rarely shrubby, the leaves are generally alternate, hollow stems, usually exstipulate, the petioles are often large and sheared at the base, the inflorescence is usually a compound umbel, and the flowers are generally hermaphrodite [2]. Apiaceae is a large family in terms of number of plants and composed of more than 3,700 species belonging to 434 genera all around the world [3]. In Turkey, this family is represented by about 102 genus and 465 species, from which 130 are endemic, with a 30\% endemism rate [4-6]. Plants of this family, generally known as carrot or parsley, are mostly aromatic and medicinally important, and are well known with regard to variability and rich profile of secondary

Corresponding author: Ömer Kilic, associate professor, research fields: botanic, biochemical systematic, plant systematic, plant essential oil and ethnobotany. metabolites, especially essential oils [7]. Umbelliferae family is rich in secondary metabolites and embodies numerous genera of high economic and medicinal value yielding flavonoids, coumarins, acetylenes, terpenes and essential oils, and it is well known that occurrence of essential oils and oleoresins is a characteristic feature of this family [8]. In addition, the plants that have particular flavors and odor are largely used in traditional medicine in many parts of the world [9].

Pimpinella $\mathrm{L}$. is represented about 150 species in the world [10] and approximate 30 taxa in the flora of Turkey $[2,6] . \quad P$. tunceliana is an endemic, Anatolia-Turanian element and new species, which was introduced by Prof. Şinasi Yıldırımlı to the world of science. The name of the new species $P$. tunceliana is derived from Tunceli province, and International Union for Conservation of Nature (IUCN) red list category must consider this new species as critically endangered (CR) [11].

Some Pimpinella species tea is used for children's flatulence, upper respiratory tract problems, cough suppressant and bronchial asthmatic attacks [12]. Trans-anethole is generally the major component of 
Pimpinella oil [13]. P. anisum is useful in destroying body lice [14], head lice and itching insects, and the oil can be used by itself, which makes it helpful for pediculosis that the skin conditions caused by lice [15]. It can also be used for scabies [16], where it may be applied externally as ointment [17]. Furthermore, seed and essential oil of some Pimpinella species are used in aromatherapy to facilitate to ease difficulty in breathing and used in folk medicine as an antispasmodic agent [18]. Some members of Pimpinella were cultivated by Egyptians, Greeks and Romans for their aromatic seeds, which have been used in medicine and as a condiment [19]. In addition, the fruits of Pimpinella have been used for medicine, perfumery and in cooking [20].

Pimpinella oil generally is colorless to pale yellow liquid with strong, sweet-spicy, licorice-like odor [21]. The concentration of essential oil of different species of Pimpinella depends not only on genetic resources but also on the development of fruits. It was observed that a significant change in essential oil concentration occurred during the development of fruit with the maximum at waxy stage [22].

Essential oil composition of some Apiaceae and Pimpinella taxa has been reported previously [23-31]. However, to the best of our knowledge, no essential oil content of $P$. tunceliana has been studied. Therefore, the objective of the present study was to examine the essential oil of $P$. tunceliana growing wild in the Eastern part of Turkey for the first time.

\section{Materials and Methods}

\subsection{Plant Materials}

P. tunceliana Y1ld. was collected for the first time as type specimen from Turkey, B7 Tunceli: Ovacık, Munzur mountains, Karagöl kepez valley, Dilap plateau, 1,750-2,250 m, July 7, 1980, and second gathering was from B7 Tunceli: Nazimiye, enter of Büyükyurt (Hakis) village, mixed forestry, 1,500 m, May 31, 2015. Voucher specimens were deposited in Ylldırımlı and Hacettepe University herbariums.

\subsection{Head Space-Solid Phase Microextraction (HS-SPME) Procedure}

Dried aerial part powder of $5 \mathrm{~g}$ plant samples were carried out by a head space solid phase microextraction (HS-SPME) method using a divinylbenzene/carboxen/polydimethylsiloxane fiber, with $50 / 30 \mu \mathrm{m}$ film thickness. Before the analysis, the fiber was conditioned in the injection port of the gas chromatography as indicated by the manufacturer. For each sample, $5 \mathrm{~g}$ of plant samples, previously homogenized, were weighed into a $40 \mathrm{~mL}$ vial; the vial was equipped with a "mininert" valve. The vial was kept at $35^{\circ} \mathrm{C}$ with continuous internal stirring and the sample was left to equilibrate for $30 \mathrm{~min}$; then, the SPME fiber was exposed for $40 \mathrm{~min}$ to the headspace while maintaining the sample at $35^{\circ} \mathrm{C}$. After sampling, the SPME fiber was introduced into the gas chromatography injector, and was left for $3 \mathrm{~min}$ to allow the analytes thermal desorption. In order to optimize the technique, the effects of various parameters, such as sample volume, sample headspace volume, sample heating temperature and extraction time were studied on the extraction efficiency as previously reported by Verzera et al. [32].

\subsection{Gas Chromatograph-Mass Spectrometer (GC-MS) Analysis}

A Varian 3800 gas chromatograph with a Varian 2000 ion trap mass spectrometer was used with injector temperature $-260 \quad{ }^{\circ} \mathrm{C}, \quad$ injection mode — splitless, column-60 m, CP-Wax 52 $\mathrm{CB}-0.25 \mathrm{~mm}$ inner diameter and $0.25 \mathrm{~mm}$ film thickness. The oven temperature was programmed as follows: $45^{\circ} \mathrm{C}$ held for $5 \mathrm{~min}$, then increased to $80^{\circ} \mathrm{C}$ at a rate of $10{ }^{\circ} \mathrm{C} / \mathrm{min}$ and to $240{ }^{\circ} \mathrm{C}$ at $2{ }^{\circ} \mathrm{C} / \mathrm{min}$. The carrier gas was helium and used at a constant pressure of $10 \mathrm{psi}$; the transfer line temperature was $250^{\circ} \mathrm{C}$; the ionisation mode was electron impact (EI); acquisition ion range was from $40 \mathrm{~m} / \mathrm{z}$ to $200 \mathrm{~m} / \mathrm{z}$; scan rate was $1 /$ us. The compounds were identified using the NIST mass spectral library and verified by 
the retention indices which were calculated as the method described by Van den Dool and Kratz [33]. The relative amounts were calculated on the basis of peak-area ratios. The identified constituents of $P$. tunceliana are listed in Table 1.

\section{Results and Discussion}

In this study, major compounds of $P$. tunceliana were $\beta$-caryophyllene (13.9\%), $\beta$-bisabolene $(10.4 \%)$, anethole $(9.3 \%)$, sabinene $(7.5 \%)$, limonene $(6.9 \%)$ and germacrene D (6.8\%) (Table 1). Similarly, $\beta$-caryophyllene was detected as the main compound in different parts of $P$. kotschyana from Iran [23]. However in another study, $\beta$-caryophyllene was not determined among the main constituents of $P$. anisetum and P. flabellifolia (Boiss.) Benth. \& Hook. ex Drude from Turkey [34]. Arslan et al. [35] recorded that anethole was the main compound of anise essential oil; like the research in this study, anethole $(9.3 \%)$ was detected as one of the main components of $P$. tunceliana oil (Table 1). The major constituents in stem/leaves (SL) and flowers (F) of $P$. aurea DC. were $\alpha$-pinene (SL: $13.0 \%$; F: 1.6\%), limonene (SL: 21.0\%; F: 9.0\%), viridiflorol (SL: 13.0\%; F: 33.0\%) and $\beta$-bisabolene (SL: 4.0\%; F: $30.0 \%)$ [24-26]. Similarly, limonene (6.9\%) and $\beta$-bisabolene (10.4\%) were detected as the main compounds of $P$. tunceliana oil; whereas viridiflorol was not found in P. tunceliana oil and $\alpha$-pinene $(0.8 \%)$ was found in low amount in this research (Table 1). The aerial parts of $P$. anisetum Boiss. \& Ball. and $P$. flabellifolia (Boiss.) Benth. ex Drude species were analyzed by GC and GC-MS, and the major constituents of $P$. anisetum were (E)-anethole (82.8\%) and methyl chavicol (14.5\%); limonene (47.0\%), (E)-anethole (37.9\%) and $\alpha$-pinene $(6.0 \%)$ were found to be the major constituents of $P$. flabellifolia [36].

Terpenes play a board range of physiological and ecological roles, including plant primary metabolism, protection against herbivores and pathogens, attractants for pollinators and as allelopathic agent. Other economically important terpenes include cartenoid
Table 1 The identified constituents of $P$. tunceliana.

\begin{tabular}{|c|c|c|}
\hline Constituents & RRI & Percent $(\%)$ \\
\hline$\alpha$-pinene & 1,032 & 0.8 \\
\hline Camphene & 1,066 & 1.8 \\
\hline$\beta$-pinene & 1,115 & 2.6 \\
\hline Sabinene & 1,130 & 7.5 \\
\hline$\delta$-3-carene & 1,142 & 0.2 \\
\hline Myrcene & 1,165 & 0.5 \\
\hline$\alpha$-phellandrene & 1,180 & 0.2 \\
\hline Limonene & 1,204 & 6.9 \\
\hline$\beta$-phellandrene & 1,210 & 1.1 \\
\hline$\beta$-ocimene & 1,255 & 0.4 \\
\hline Geijerene & 1,325 & 3.6 \\
\hline$\gamma$-Terpinene & 1,354 & 0.1 \\
\hline$p$-cymene & 1,362 & 0.1 \\
\hline Terpinolene & 1,370 & 0.4 \\
\hline Octanal & 1,385 & 0.2 \\
\hline Linalyl acetate & 1,396 & 0.3 \\
\hline Methyl-chavicol & 1,415 & 3.1 \\
\hline Cis-anethole & 1,432 & 2.2 \\
\hline$\alpha$-copaene & 1,456 & 0.3 \\
\hline$\alpha$-cubebene & 1,465 & 0.7 \\
\hline Trans-Sabinene hydrate & 1,472 & 0.1 \\
\hline Linalool & 1,475 & 0.4 \\
\hline Bornyl acetate & 1,480 & 1.2 \\
\hline$\gamma$-elemene & 1,485 & 3.1 \\
\hline$\alpha$-copaene & 1,492 & 0.3 \\
\hline Aromadendrene & 1,502 & 0.6 \\
\hline Bicyclogermacrene & 1,520 & 2.8 \\
\hline$\beta$-bourbenene & 1,535 & 1.3 \\
\hline$\beta$-cubebene & 1,542 & 0.2 \\
\hline$\delta$-cadinene & 1,580 & 0.5 \\
\hline$\beta$-caryophyllene & 1,610 & 13.9 \\
\hline$\beta$-farnesene & 1,665 & 1.4 \\
\hline$\alpha$-humulene & 1,682 & 0.6 \\
\hline$\gamma$-Muurolene & 1,702 & 1.7 \\
\hline Germacrene D & 1,715 & 6.8 \\
\hline$\beta$-bisabolene & 1,735 & 10.4 \\
\hline Bicyclogermacrene & 1,752 & 2.2 \\
\hline$\delta$-cadinene & 1,765 & 0.2 \\
\hline$\beta$-sesquiphellandrene & 1,780 & 0.4 \\
\hline Myrtenol & 1,805 & 0.1 \\
\hline (E)-anethole & 1,862 & 9.3 \\
\hline Caryophyllene oxide & 1,989 & 1.2 \\
\hline Methyl eugenol & 2,028 & 1.3 \\
\hline Spathulenol & 2,125 & 0.7 \\
\hline$\alpha$-bisabolol & 2,210 & 0.1 \\
\hline Carvacrol & 2,224 & 0.2 \\
\hline$\alpha$-cadinol & 2,240 & 0.2 \\
\hline Methyl butyrate & 2,589 & 1.8 \\
\hline Pentadecanoic acid & 2,920 & 0.1 \\
\hline Hexadecanoic acid & 2,931 & 0.2 \\
\hline Total & & 96.3 \\
\hline
\end{tabular}

RRI: relative retention index. 
pigments, natural rubber and the essential oils [37]. The major constituent of a phenylpropanoid (comprising $80 \%$ to $90 \%$ of the oil) and typical odor and flavor carrier of the fruit oil of $P$. anisum oil is trans-anethole [21]. Trans-anethole is of medicinal importance because of its carminative and expectorant effect. The isomeric methylchavicol (estragol) accounts for $4 \%$ of the oil composition; it possesses an anise, like smell, but lacks the sweetish taste [38]. The essential oil of the herb of Pimpinella contain considerable amount of sesquiterpenes hydrocarbon, such as germacrene-D, $\beta$-bisbolene, $\beta$-himachalene, $\alpha$-zingiberene and curcumene. The root oil is characterized by the presence of $\beta$-bisabolene, pregeijerene and its cope-rearrangement product geijerene [38]. In previous studies, Rodrigues et al. [39] extracted $3.1 \%-10.6 \%$ essential oil by the supercritical fluidextraction (SFE) method. The oil contained anethole $(90 \%), \gamma$-himachalene $(2 \%-4 \%)$, $p$-anisaldehyde (1\%), methylchavicol $(0.9 \%-1.5 \%)$, cispseudoisoeugenyl-2-methylbutyrate $(3 \%)$ and t-pseudoisoeugenyl-2-methylbutyrate $(1.3 \%)$ as the major constituents. Tabanca et al. [40] analyzed essential oils of 15 Pimpinella taxa, and as a result, 140 compounds were identified, which included mono, sesqui trinorsesquiterpenoids, propenylphenols and pseudoisoeugenols; so, trinorsesquiterpenoids and phenylpropanoid are the chemical markers of the Pimpinella taxa.

The anis root oil was characterized by a high content of $\beta$-bisabolene $(52.46 \%)$ and pregeijerene $(12.78 \%)$. The main compounds of the root oil of Pimpinella peregrina were $\beta$-sesquiphelandrene (19.83\%), epoxy-pseudoisoeugenyl-2-methylpropionate (11.84\%), pregeijerene $(11.01 \%)$ and $\beta$-bisabolene (10.00\%). The root oil of $P$. major mainly included epoxy-pseudoisoeugenyl tiglate $(56.53 \%)$ and pregeijerene $(10.36 \%)$; major compounds of the root oil of Pimpinella saxifrage were epoxy-pseudoisoeugenyl-2-methylbutyrate (46.24\%) and pregeijerene (9.18\%) [41]. If this study compared with cited work, essential oil composition of $P$. tunceliana showed differences in respect to some constituents owing to the genetic, local, climatic, different plant parts, different analysis methods and seasonal factors etc., but major compounds of Pimpinella taxa are generally the same. P. aromatica Bieb. from Turkey was characterized by chavicol $(91.96 \%)$ and (E)-anethole (7.22\%) [42]. It is noteworthy that, methyl chavicol (3.1\%) was detected in low amount in P. tunceliana (Table 1). In herbal medicine, the mild sedative properties of hops are due to the presence of $\beta$-caryophyllene [43]; in vitro studies, it was demonstrated the cytotoxic activity of the $\beta$-caryophyllene against breast cancer cells [44]. In this study, $\beta$-caryophyllene was determined in high amount from P. tunceliana (13.9\%), so P. tunceliana demonstrated their applicability for medicinal, cosmetic and pharmaceutical purposes with these results.

\section{Conclusions}

In conclusion, the present work is the first report on the composition of essential oils obtained from the aerial parts of $P$. tunceliana. These results showed that the extract compounds from the same plant of different chemotype vary significantly. This variation is also observed in other species due to different localities. Analyzing previously published Pimpinella taxa reports for the investigated species and for $P$. tunceliana showed some variations concerning essential oil composition. Comparison the results of $P$. tunceliana in this paper with the other literatures showed significant differences for the extracts, which can be attributed to different analysis method, either due to climatic, factors or genetic differences of the plants. Sample extracts from P. tunceliana was rich in essential oil compounds. The biologic activity of Pimpinella samples may be related to its richness in secondary metabolites, especially essential oils. $\beta$-bisabolene, $\beta$-caryophyllene, germacrene $\mathrm{D}$, sabinene and limonene were found to be the reason of chemotypes of $P$. tunceliana. 


\section{References}

[1] Judd, W. S., Campbell, C. C., Kelogg, E. A., Stevens, P. F., and Donoghue, M. J. 2007. Plant Systematics: A Phylogenetic Approach, 3rd ed.. Sunderland, MA: Sinauer Associates.

[2] Davis, P. H. 1972. Flora of Turkey and East Aegean Islands. Vol. 4. Edinburgh: Edinburgh University Press.

[3] Stevens, P. F. 2000. "On Characters and Character States: Do Overlapping and Non-overlapping Variation, Morphology and Molecules All Yield Data of the Same Value." In Homology and Systematics: Coding Characters for Phylogenetic Analysis, edited by Scotland, R., and Pennington, R. T. New York: Taylor and Francis, 81-105.

[4] Ozhatay, N., and Kultur, S. 2006. "Check-List of Additional Taxa to the Supplement Flora of Turkey III." Turk. J. of Bot. 30: 281-316.

[5] Ozhatay, N., Kultur, S., and Aslan, S. 2009. "Check-List of Additional Taxa to the Supplement Flora of Turkey IV." Turk. J. of Bot. 33: 191-226.

[6] Ozhatay, N., Kultur, S., and Gurdal, M. B. 2011. "Check-List of Additional Taxa to the Supplement Flora of Turkey V." Turkish J. of Bot. 35: 589-624.

[7] Hegnauer, R. 1973. Chemotaxonomy of Plants: An Overview of the Distribution and Systematic Significance of Plant Materials. London: Academic Press, 389-427.

[8] Gijbels, M. J. M., Scheffer, J. J. C., Baerheim, A., and Svendsen, A. 1979. "Flavourings: Production, Composition, Applications, Regulations." Riv. Ital. Essenze 8: 61-335.

[9] Plunkett, G. M., and Downie, S. R. 1999. "Major Lineages within Apiaceae Subfamily Apioideae: A Comparison of Choloroplast Restriction Site and DNA Sequence Data." American J. of Bot. 86 (7): 1014-26.

[10] Konemann, B. 1999. The Illustrated A-Z of over 10,000 Garden Plants and How to Cultivate Them. Hong Kong: Gordon Cheers Publication, 51-3.

[11] Yıldırımlı, Ş. 2010. "Some New Taxa, Records and Taxonomic Treatments from Turkey." Ot Sist. Bot. Derg. 17 (2): 1-14.

[12] Fluck, H. 1988. Medicinal Plants. Slough, United Kingdom: W. Foulsham \& Co Ltd.

[13] Waumans, D., Bruneel, N., and Tytgat, J. 2006. "Anise Oil as a Precursor for 5-Methoxybenzaldehydes." DEA Microgram Journal 2 (1): 66-70.

[14] Spoerke, D. G. 1980. Herbal Medications. Santa Barbara, CA: Woodbridge Press Publ. Co., 83.

[15] Newall, C. A., Anderson, L. A., and Phillipson, J. D. 1996. Herbal Medicines: A Guide for Health-Care Professionals. London: The Pharmaceutical Press.

[16] Ody, P. 1993. Handbook of over the Counter Herbal
Medicines. London: Kyle Cathie.

[17] Hoffmann, D. 1991. Thorsons Guide to Medicinal Herbalism: A Comprehensive and Practical Introduction. London: Thorsons.

[18] Price, S. 1987. Practical Aromatherapy. London: Thorsons.

[19] Fujımatu, E., Ishıkawa, T., and Kitajıma, J. 2003. "Aromatic Compound Glucosides, Alkyl Glucoside Andglucide from the Fruit of Anise." Phytochem. 63 (5): 609-16.

[20] Santos, P. M., Figueiredo A. C., Oliveira, M. M., Barroso, J. G., Pedro, L. G., and Deans, S. G. 1998. "Essential Oils from Hairy Root Cultures and from Fruits and Roots of $P$. anisum." Phytochem. 48 (3): 455-60.

[21] Orav, A., Raal, A., and Arak, E. 2008. "Essential Oil Composition of Pimpinella anisum Fruits from Various European Countries." Nat. Prod. Res. 22 (3): 227-32.

[22] Omidbaigi, R., Hadjiakhoondi, A., and Saharkhiz, M. 2003. "Changes in Content and Chemical Composition of Pimpinella anisum L. Oil at Various Harvest Time.” J. of Essent. Oil Bearing Plants 6 (1): 46-50.

[23] Askari, F., Teimouri, M., and Sefidkon, F. 2005. "Chemical Composition and Antimicrobial Activity of Pimpinella kotschyana Boiss. Oil in Iran.” J. of Essent. Oil Bearing Plants 14 (1): 124-30.

[24] Askari, F., Sefidkon, F., and Mirza, M. 1998. "Quantitative and Qualitative of Essential Oil Pimpinella anisum." Research and Reconstruction 38: 70-3.

[25] Askari, F., and Sefidkon, F. 2006. "Essential Oil Composition of Pimpinella affinis Ledeb. from Two Localities in Iran.” Flavour Fragr. J. 21 (5): 754-6.

[26] Askari, F., and Sefidkon, F. 2007. "Essential Oil Composition of Pimpinella tragioides (Boiss.) Benth. et Hook. from Iran.” J. Essent. Oil Res. 19 (1): 54-6.

[27] Kilic, O. 2014. "Essential Oils Composition of Two Endemic Umbelliferae Herbs Growing Wild in Turkey." J. of Agric. Sci. and Tech. A 4: 435-42.

[28] Kilic, O. 2014. "Essential Oil Composition and Potential Usefulness of Two Bupleurum L. Species from Turkey." Turkish J. of Agric. and Nat. Sci. 1 (3): 445-9.

[29] Kilic, O. 2014. "Essential Oil Composition of Two Apiaceae Species from Bingol (Turkey)." Tr. J. Nature Sci. 3 (1): 18-21.

[30] Kilic, O. 2014. "Essential Oil Composition of Two Pimpinella L. Species from Turkey." Muş Alparslan Üniv. Fen Bil. Der. 2 (2): 290-4.

[31] Kilic, O. 2015. "Essential Oil Composition of Ferula orientalis L. from Different Localities of Turkey and a Chemotaxonomic Approach." Düzce Univ. J. of Sci. \& Tech. 3: 251-7.

[32] Verzera, A., Zıno, M., Condurso, C., Romeo, V., and Zappala, M. 2004. "Solid-Phase Microextraction and Gas 
Chromatography/Mass Spectrometry for the Rapid Characterization of Semi-hard Cheeses." Anal. Bioanal. Chem. 380 (7-8): 930-6.

[33] Van Den Dool, H., and Kratz, P. D. 1963. "A Generalization of the Retention Index System Including Linear Temperature Programmed Gas-Liquid Partition Chromatography." J. Chromatography 11: 463-71.

[34] Tepe, B., Akpulat, H. A., Sokmen, M., Daferera, D., Yumrutas, O., Aydın, E., Polissiou, M., and Sokmen, A. 2006. "Screening of the Antioxidative and Antimicrobial Properties of the Essential Oils of Pimpinella anisetum and Pimpinella flabellifolia from Turkey." Food Chem. 97 (4): 719-24.

[35] Arslan, N., Gürbüz, B., and Sarihan, E. O. 2004. "Variation in Essential Oil Content and Composition in Turkish Anise (Pimpinella anisum L.) Populations." Turkish J. Agric. Forestry 28: 173-7.

[36] Kubeczka, K. H., and Ullmann, I. 1980. “Occurrence of 1, 5-Dimethylcyclodeca-1, 5, 7-Triene (Pregeijerene) in Pimpinella Species and Chemosystematic Implications." Biochem. Syst. and Ecol. 8 (1): 39-41.

[37] Croteau, R., Kutchan, T. M., and Lewis, N. G. 2000. "Natural Products (Secondary Metabolites)." In Biochemistry and Molecular Biology of Plants. Rockville, Maryland: American Society of Plant Physiologists, 1250-318.

[38] Santos, P. M., Figueiredo, A. C., Oliveira, M. M., Barroso, J. G., Pedro, L. G., Deans, S. G., Youns, A. K.
M., and Scheffer, J. C. 1998. "Essential Oils from Hairy Root Culture and from Fruits and Roots of Pimpinella anisum." Phytochem. 48 (3): 455-60.

[39] Rodrigues, V. M., Rosa, P. T. V., Marques, M. O. M., Petenale, A. S., and Meireles, M. A. 2003. "Supercriticial Extraction of Essential Oil from Aniseed (Pimpinella anisum) Using $\mathrm{CO}_{2}$ Solubility, Kinetics and Composition Data." J. Agric. Food Chem. 51 (6): 1518-23.

[40] Tabanca, N., Demirci, B., Ozek, T., Kirimer, N., Baser, K. H. C., Bedir, E., Khan, I. A., and Wedge, D. E. 2006. "Gas Chromatographic-Mass Spectrometric Analysis of Essential Oil from Pimpinella Species Gathered from Central and Northern Turkey." J. Chromatogr. A 1117 (2): 194-205.

[41] Shiva, M., Abdolhossein, R., and Hefzollah, M., 2009. "Composition of the Essential Oils of Pimpinella anisactis Rech. f. and Pimpinella saxifraga L. from Iran." Journal of Essential Oil Research 21 (2): 146-8.

[42] Baser, K. H. C., Özek, T., Duman, H., and Guner, A. 1996. "Essential Oil of Pimpinella aromatica Bieb. from Turkey." Journal of Essential Oil Research 8 (4): 463-4.

[43] Asakawa, Y., Toyota, M., and Ishida, T. 1998. "Biotransformation of 1, 4-Cineole, a Monoterpene Ether." Xenobiotica 18 (10): 1129-34.

[44] DeBarber, A. E., Bleyle, L. A., Roullet, J. B., and Koop, D. R. 2004. "Omega-Hydroxylation of Farnesol by Mammalian Cytochromes P450.” Biochem. Biophysics Acta 1682: 18-27. 